\title{
GC/MS Analysis and Potential Cytotoxic Activity of Haplophyllum tuberculatum Essential Oils Against Lung and Liver Cancer Cells
}

\author{
Omar Mohamed Mohamed Sabry ${ }^{1,2^{*}}$, Abeer Mohamed El Sayed'and Salmin Khalid Alshalmani \\ 'Department of Pharmacognosy, Faculty of Pharmacy, Cairo University, Kasr El-Einy Street, 11562, Cairo, Egypt. \\ ${ }^{2}$ Department of Pharmacognosy, Faculty of Pharmacy, Benghazi University, Benghazi, Libya.
}

\begin{abstract}
Background: Haplophyllum tuberculatum is a plant belongs to family rutacee. It is rich in volatile oils, fixed oils, alkaloids, and furanocoumarins. It is well known for the huge number of folkloric uses in middle east. Objective: The aim of this study is to establish the chemical composition of the essential oils of Libyan $\mathrm{H}$. tuberculatum and to investigate their cytotoxic potentialities.Materials and Methods: The essential oils of the aerial parts and flowers of $H$. tuberculatum growing in Libya were prepared by hydrodistillation. GC/MS analyses were performed on a Shimaduz capillary gas chromatograph (GC 17A ver.3) instrument directly coupled to mass spectrometer-MS QP5050A. Oil A and F of $H$. tuberculatum at different concentrations $(0-50 \mu \mathrm{g} / \mathrm{ml})$ in DMSO were tested for cytotoxicity against human tumor cell lines. Results: Oil yield was found 0.4 and 1.5 (v/w \%) on dry weight basis respectively. GC/MS analysis resulted in identification of total 35 compounds. 15 compounds were common to both oils. oil $A$ of $H$. tuberculatum exhibited antitumor activities against. liver carcinoma
\end{abstract}

cell line (HEPG2) and lung carcinoma cell line (H1299) $4.7 \mu \mathrm{g} / \mathrm{ml}$ and 4.1 $\mu \mathrm{g} / \mathrm{ml}$. Conclusion: Essential oil of the aerial parts of $H$. tuberculatum is potentially active against lung (H-1299), and liver (HEPG2) carcinoma cell lines. The observed cytotoxic, activities can be attributed to the dominance of $\alpha$ and $\gamma$-terpinene in this oil.

Key words: Haplophyllum tuberculatum, Essential oils, Cytotoxicity, Lung cancer, Liver cancer.

Address for Correspondence:

Dr. Omar Mohamed Mohamed Sabry, Department of Pharmacognosy, College of Pharmacy, Cairo University, Kasr El-Einy Street, Cairo 11562, Egypt.

Phone no: +201114886724

E-mail: omar.sabry@cu.edu.eg

DOI : 10.5530/pj.2016.1.14

\section{INTRODUCTION}

In Egypt the flowering aerial parts of $H$. tuberculatum are used as a drink to relieve fever, for abdominal upset, anemia, gastric pains, intestinal worms, malaria, as aphrodisiac, and the decoction is used for rheumatic pains. ${ }^{1}$ In Oman, the leaves are used as a remedy for headaches and arthritis and also used for treatment of skin infections, discoloration and parasitic diseases. ${ }^{2}$ In Saudi Arabia, H. tuberculatum is used to treat malaria, rheumatoid arthritis and gynecological disorders, ${ }^{3}$ while in Sudan the herb is used as an antispasmodic, to treat allergic rhinitis and breathing difficulties. ${ }^{4}$ The plant is rich in alkaloids, fixed oils, volatile oils and furanocoumarins..$^{5-8}$ No published report was recorded concerning the analysis of the volatile oil of the aerial parts and the flower of Libyan H. tuberculatum and their biological potentialities.

\section{MATERIALS AND METHODS}

\section{Plant material}

Samples of the aerial parts and flowers of Haplophyllum tuberculatum (Forssk) A. Juss (Rutaceae) were obtained from Benghazi, Libya, identified by Dr. Reem Samir Hamdy, Lecturer of Plant Taxonomy, Botany Department, Faculty of Science, Cairo University, Giza, Egypt. A voucher specimen of the aerial parts and the flowers of H. tuberculatum, were kept in the herbarium of Department of Pharamacognosy, Faculty of Pharmacy, Cairo University as a reference material specimen No. 2015224.

\section{Preparation, characterization and analysis of the essential oil}

Fresh samples of aerial parts and flowers of $H$. tuberculatum (500 g) were subjected separately to hydro-distillation. The percentage yield was calculated on dry weight $(\mathrm{v} / \mathrm{w})$ basis of the plant materials. The essential oil was dried over anhydrous sodium sulfate and kept refrigerated until analysis.

\section{Sample preparation for GC/FID and GC/MS analysis}

Samples prepared by mixing $5 \mu \mathrm{l}$ of dehydrated essential oil with approximately one $\mathrm{ml}$ of dichloromethane in auto sampler vials. Injection volume was $1 \mu \mathrm{l}$ injected directly to GC-FID and GC-MS.

\section{Gas chromatography-mass spectrometry analysis (GC/MS)}

GC/MS analyses were performed on a Shimaduz capillary gas chromatograph (GC 17A ver.3) instrument directly coupled to mass spectrometer-MS QP5050A. Capillary column SLB-5ms (30 m x 0.25 $\mathrm{mm}$, film thickness $0.25 \mu \mathrm{m}$ ) was used under the following condition: oven temperature programmed from $40^{\circ} \mathrm{C}(3 \mathrm{~min})$, then temperature increased at rate $12^{\circ} \mathrm{C} / \mathrm{min}$ to $180^{\circ} \mathrm{C}$ where it is hold for $5 \mathrm{~min}$, then temperature increased at rate $40^{\circ} \mathrm{C} / \mathrm{min}$ to reach $240^{\circ} \mathrm{C}$, where it is finally hold for $5 \mathrm{~min}$. The injector temperature was $240^{\circ} \mathrm{C}$ and was set at split ratio 1:54. Carrier gas was $\mathrm{He}$ at flow rate $0.9 \mathrm{ml} / \mathrm{min}$. The mass spectrometer operated on electronic (EI) ionization mode at $70 \mathrm{eV}$ with scan range 40-500. The transfer line temperature was $230^{\circ} \mathrm{C}$.

\section{Gas chromatography analysis (GC-FID)}

The GC analysis was carried out using Shimaduz GC gas chromatograph (GC-17 ver.3) system. FID detector temperature was $240^{\circ} \mathrm{C}$. To obtain the same elution order with GC/MS simultaneous auto injection was done on a duplicate of the same operational conditions. Identification of the essential oil components were carried out by comparing their relative retention times with those of authentic samples or by comparing their relative retention indices (RRI). The later were computed using a mixture of a continuous series of $n$-alkane hydrocarbons (C4-C28) run on SLB$5 \mathrm{~ms}$ (non-polar) column using the same conditions as described above. The components of the oils were fully unambiguously identified by their mass spectral fragmentation patterns with those reported in computerized MS-data bank spectral libraries (NIST and WILEY) ${ }^{10}$ or reported in the literature. ${ }^{11-12}$ The compounds are arranged in order to GC elution on SLB-5ms capillary column. Relative percentages were calculated based on the GC-FID peak areas without the use of correction factors and are compiled.

\section{In vitro screening for cytotoxic activity}

Human tumor cell lines: lung carcinoma cell line (H-1299) and liver carcinoma cell line (HEPG2), maintained in the laboratory of the 
Cancer Biology Department of National Cancer Institute, Cairo, Egypt, were used. Oil A and $\mathrm{F}$ of $\mathrm{H}$. tuberculatum at different concentrations $(0-50.000 \mu \mathrm{g} / \mathrm{ml})$ in DMSO were tested for cytotoxicity against the forementioned human tumor cell line adopting sulforhodamine B stain (SRB) assay. ${ }^{13}$ The relation between surviving fractions and oil concentration was plotted to get the survival curve of each tumor cell line after the application of the specific concentration. The results were compared to those of the standard cytotoxic drug, Doxorubicin (10 mg Adriamycin hydrochloride, in $5 \mathrm{ml}$ IV injection, Pharmacia, Italy) at the same concentrations. The dose of the test solutions which reduces survival to $50 \%$ $\left(\mathrm{IC}_{50}\right)$ was calculated.

\section{Determination of median lethal dose $L D_{50}$}

The $\mathrm{LD}_{50}$ of the volatile oils was determined according to the procedures developed by Karber (1941). ${ }^{14}$

\section{Drugs and chemicals}

Doxorubicin (10 mg Adriamycin hydrochloride, in $5 \mathrm{ml}$ IV injection, Pharmacia, Italy).

\section{Statistical analysis}

All data were expressed as mean \pm SE and the statistical significance was evaluated using the ANOVA test followed by Duncan's multiple range tests.

\section{RESULTS}

\section{GC/MS analysis of essential oils}

Hydro distillation of the aerial parts and flowers of $H$. tuberculatum yielded 0.4 and $1.5 \% \mathrm{v} / \mathrm{w}$ of clear yellow colored oil exhibiting a characteristic agreeable odor. The specific gravity and refractive index were $0.975,0.968$ and $1.487,1.495$, respectively. GC-MS analysis of different oil samples of $H$. tuberculatum revealed relevant quantitative and qualitative variability. The components were categorized according to their chemical nature and listed in Table 1. The oils of the aerial parts (A) and flowers (F) of $H$. tuberculatum showed approximately similar amounts of hydrocarbons and oxygenated constituents The lower percentage of hydrocarbons was recorded for the oil F (78.28\%). Meanwhile, the highest percentage of hydrocarbon constituents was found in oil A (89.82\%).

Terpene hydrocarbons were detected in appreciable amounts in oil A $(82.34 \%)$. Monoterpenes prevailed in the sample A (75.78\%) while, in sample $\mathrm{F}(72.81 \%)$ with the major a-terpinene ranged from (26.40$24.45 \%)$ and $\beta$-terpinene ranged from (17.13-14.40\%), respectively. Sesquiterpenes e.g. Zingiberine and $\beta$-sesquiphellandrene were detected in oil A in traces only $(0.36 \%)$ and $(0.03 \%)$. Other monoterpene hydrocarbons constituents detected in high amounts were: $\alpha$-pinene (1.43$1.33 \%), \beta$-myrcene (5.69-6.05\%) and 3-carene (3.87-5.43\%), respectively. The profile of both samples were characterized by the presence of $\beta$-phellandrene (10.0-10.40\%), 3,4-dimethyl-1,5-cyclooctadiene (6.036.67\%) and $\beta$-myrecene (5.69-6.04\%). In oil A Oxygenated monoterpenes were represented by 1,8 cineole (1.67\%) and piperitone $(5.55 \%)$.

\section{Evaluation of cytotoxic activity}

On assessing the cytotoxic activity under the experimental condition adopted and from data displayed in Table 2 it could be concluded that the oil A of $H$. tuberculatum exhibited variable antitumor activities against the two tested cell line viz. liver carcinoma cell line (HEPG2) and lung carcinoma cell line (H1299). In this respect, the oil A of H. tuberculatum demonstrated the lowest IC50\% when tested against H-1299 and HEPG2 cells $(4.7 \mu \mathrm{g} / \mathrm{ml}$ and $4.1 \mu \mathrm{g} / \mathrm{ml})$ respectively.

On the other hand, the oil F showed relatively higher IC50\% against H-1299 and HEPG2 cells $(42.3 \mu \mathrm{g} / \mathrm{ml}$ and $19.7 \mu \mathrm{g} / \mathrm{ml})$ respectively, which is comparable to the standard cytotoxic drug, doxorubicin (Table 3-4). Results obtained during assessment of the cytotoxic potential of
Table 1: Percentage composition of essential oil of the aerial parts and flowers of $H$. tuberculatum

\begin{tabular}{|c|c|c|c|c|}
\hline No. & Compound & ${ }^{*} \mathbf{R I}$ & $A(\%)$ & F (\%) \\
\hline 1 & 1-Butanol-3-methylacetate & 880 & 0.52 & 0.77 \\
\hline 2 & a-Thujene & 929 & 0.32 & - \\
\hline 3 & $\alpha$-Pinene & 937 & 1.43 & 1.33 \\
\hline 4 & Pentanol & 972 & - & 0.02 \\
\hline 5 & $\begin{array}{l}\text { Cyclohexen,1-methy-4-(1- } \\
\text { ethylethyldiene }\end{array}$ & 977 & 1.12 & - \\
\hline 6 & $\beta$-Myrcene & 990 & 5.69 & 6.05 \\
\hline 7 & Pentane-2,2-dimethyl & 1003 & 0.08 & - \\
\hline 8 & Octanal & 1005 & 0.36 & - \\
\hline 9 & Isovaleric acid isobutyl ester & 1010 & 0.33 & - \\
\hline 10 & a-Phellandrene & 1010 & - & 2.33 \\
\hline 11 & 3-Carene & 1013 & 3.87 & 5.43 \\
\hline 12 & Cineol 1,4 & 1020 & 3.82 & 0.08 \\
\hline 13 & Iso-terpinolene & 1021 & - & 0.20 \\
\hline 14 & 2-Pentanone ethylacetone & 1025 & 0.54 & 0.28 \\
\hline 15 & Acetophenone-4'-methyl & 1029 & - & 0.27 \\
\hline 16 & Cyclooctadiene-3,7-dimethyl & 1034 & 6.03 & 6.66 \\
\hline 17 & $\beta$-phellandrene & 1036 & 10.40 & 10.00 \\
\hline 18 & Eucalyptol & 1039 & 1.67 & 0.70 \\
\hline 19 & Cis B-Ocimene & 1049 & 0.39 & 0.42 \\
\hline 20 & 1-Cyclo propyl pentane & 1074 & 0.42 & 0.25 \\
\hline 21 & Non-2-en-1-ol & 1077 & - & 0.49 \\
\hline 22 & $\mathrm{n}$-amyl iso valerate & 1099 & 0.27 & 0.43 \\
\hline 23 & Linaloal & 1101 & - & 1.38 \\
\hline 24 & Butyric acid-2-methyl & 1103 & - & 0.52 \\
\hline 25 & Isovaleric acid iso pentyl ester & 1105 & - & 2.32 \\
\hline 26 & $\mathrm{n}$-amyl isovalerate & 1108 & - & 3.23 \\
\hline 27 & Octanol (n-octan-1-ol) & 1130 & - & 0.50 \\
\hline 28 & a-Terpinen & 1133 & 26.40 & 24.45 \\
\hline 29 & $\beta$-Terpinen & 1151 & 17.13 & 14.40 \\
\hline 30 & Ocimenol & 1175 & 0.03 & 0.05 \\
\hline 31 & Trans piperitol & 1207 & - & 4.66 \\
\hline 32 & $\gamma$-Terpinen & 1219 & 9.07 & 7.76 \\
\hline 33 & Piperitone & 1267 & 5.55 & 2.07 \\
\hline 34 & (-)-Zingiberene & 1505 & 0.36 & - \\
\hline 35 & $\beta$-Sesquiphellandrene & 1540 & 0.04 & - \\
\hline & Identified components & & 95.83 & 97.05 \\
\hline & Monterpenes hydrocarbons & & 82.34 & 72.81 \\
\hline & Oxygenated monoterpenes & & 13.09 & 7.51 \\
\hline & Sesquiterpens hydrocarbons & & 0.40 & 0.00 \\
\hline & Oxygenated sesquiterpenes & & 0.00 & 0.00 \\
\hline & Aliphatic hydrocarbons & & 6.58 & 6.47 \\
\hline & Aliphatic oxygenated compounds & & 1.51 & 9.97 \\
\hline & Oxygenated components & & 13.09 & 17.77 \\
\hline & Non-oxygenated components & & 82.74 & 79.28 \\
\hline
\end{tabular}

Components are listed in order of their elution. $\mathrm{RI}^{*}$ : Relative retention index on SLB-5ms column. 
Table 2: Results of cytotoxic activity of the essential oil of $\boldsymbol{H}$. tuberculatum

\begin{tabular}{ccc}
\hline & \multicolumn{2}{c}{ IC $_{50} \boldsymbol{\mu g} / \mathrm{mI}$} \\
Tested Solutions & $\begin{array}{c}\text { Lung carcinoma } \\
\text { H1299 }\end{array}$ & $\begin{array}{c}\text { Liver carcinoma } \\
\text { HEPG2 }\end{array}$ \\
\hline Essential oil A & 4.7 & 4.1 \\
Essential oil F & 42.3 & 19.7 \\
Standard drug (Doxorubicin) & 3.70 & 7.00 \\
\hline
\end{tabular}

Table 3: Drug cytotoxicity of $H$.tubrtculatum on Liver carcinoma cell line HEPG-2

\begin{tabular}{cccc} 
Conc $\boldsymbol{\mu g} / \mathbf{m l}$ & $\begin{array}{c}\text { Essential oil A } \\
\text { Mean } \pm \text { SD }\end{array}$ & Essential oil F & Doxorubicin \\
\hline $\mathbf{0 . 0 0 0}$ & $1.000 \pm 0.047$ & $1.000 \pm 0.047$ & $1.000 \pm 0.009$ \\
$\mathbf{5 . 0 0 0}$ & $0.407 \pm 0.050$ & $0.857 \pm 0.055$ & $0.536 \pm 0.017$ \\
$\mathbf{1 2 . 0 0 0}$ & $0.311 \pm 0.065$ & $0.602 \pm 0.060$ & $0.441 \pm 0.017$ \\
$\mathbf{2 5 . 0 0 0}$ & $0.323 \pm 0.050$ & $0.423 \pm 0.029$ & $0.377 \pm 0.017$ \\
$\mathbf{5 0 . 0 0 0}$ & $0.355 \pm 0.036$ & $0.380 \pm 0.055$ & $0.338 \pm 0.011$ \\
\hline
\end{tabular}

$\mathrm{N}=6$

Table 4: Drug cytotoxicity of H.tubrtculatum on Lung carcinoma cell line H-1299

\begin{tabular}{cccc}
\hline Conc $\boldsymbol{\mu g} / \mathbf{m l}$ & Essential oil A & $\begin{array}{c}\text { Essential oil F } \\
\text { Mean } \pm \text { SD }\end{array}$ & Doxorubicin \\
\hline $\mathbf{0 . 0 0 0}$ & $1.000 \pm 0.050$ & $1.000 \pm 0.050$ & $1.000 \pm 0.057$ \\
$\mathbf{5 . 0 0 0}$ & $0.465 \pm 0.033$ & $0.593 \pm 0.041$ & $0.353 \pm 0.014$ \\
$\mathbf{1 2 . 0 0 0}$ & $0.224 \pm 0.041$ & $0.597 \pm 0.044$ & $0.339 \pm 0.007$ \\
$\mathbf{2 5 . 0 0 0}$ & $0.181 \pm 0.012$ & $0.639 \pm 0.075$ & $0.303 \pm 0.023$ \\
$\mathbf{5 0 . 0 0 0}$ & $0.230 \pm 0.032$ & $0.552 \pm 0.067$ & $0.369 \pm 0.011$ \\
\hline
\end{tabular}

$\mathrm{N}=6$

the oil H. tuberculatum are in accordance with formerly reported data related to $\gamma$-terpinene. ${ }^{15}$

\section{Determination of median lethal dose $L D_{50}$}

The 24-hours $\mathrm{LD}_{50}$ was approximately more than $0.05 \mathrm{ml} / \mathrm{kg}$ b. wt. for the essential oils. These results showed that the essential oils are safe and non-toxic.

To the best of our knowledge, this is the first report on the chemical composition of the essential oil of Libyan H. tuberculatum. Nevertheless, the composition of the essential oil from $H$. tuberculatum grown in different regions of Egypt was previously studied. ${ }^{16}$ Monoterpenes are non-nutritive dietary components found in the essential oils of herbs. $\gamma$-terpinen, the major component of the oil in the present work (26-38\%) was detected only in trace amounts in the essential oil obtained from $H$. tuberculatum in other countries. ${ }^{17-19}$ On the contrary, limonene (absent in the Libyan sample), linalool, and beta caryophyllene, were present in major quantities $(12.8 \%, 15.5 \%$ and $12.77 \%)$ in the essential oil of the $H$. tuberculatum of Iran, United Arab Emirates, Oman and Iran respectively. ${ }^{17-19}$ Moreover, the hydrocarbons, $\beta$-phellandrene, $\alpha$-pinene, and 3-carene were present in Libyan and Egyptian samples in comparable amounts. The difference in oil yield obtained and the composition of essential oil in plants were affected by genetical and environmental conditions, which is determined by growth region and harvesting time in terms of onto genetical and diurnal variability.

On assessing the cytotoxic activity under the experimental condition adopted and from data displayed in Table 3 it could be concluded that the oil A of $H$. tuberculatum exhibited variable antitumor activities against the two tested cell line viz, liver carcinoma cell line (HEPG2) and lung carcinoma cell line (H1299). In this respect, the oil A of H. tuberculatum demonstrated the lowest IC50\% when tested against H-1299 and HEPG 2 cells $(4.7 \mu \mathrm{g} / \mathrm{ml}$ and $4.1 \mu \mathrm{g} / \mathrm{ml})$ respectively. On the other hand, the oil F showed relatively higher IC50\% against H-1299 and HEPG2 cells $(42.3 \mu \mathrm{g} / \mathrm{ml}$ and $19.7 \mu \mathrm{g} / \mathrm{ml})$ respectively, which is comparable to the standard cytotoxic drug, doxorubicin (Table 3-4). Results obtained during assessment of the cytotoxic potential of the oil $H$. tuberculatum are in accordance with formerly reported data related to $\gamma$-terpinen. ${ }^{15}$ The study was the first concerning the cytotoxic activity of the essential oils of $H$. tuberculatumon tumor cell lines.

\section{CONCULSION}

In conclusion, this report was the first paper indicating the chemical composition and investigating the cytotoxic potentialities of the essential oils of Libyan $H$. tuberculatum. It is found that the essential oils of the aerial parts of Halpophyllum tuberculatum are potentially active against lung (H-1299), and liver (HEPG2) carcinoma cell lines. The observed cytotoxic, activities can be attributed to the dominance of $a$ and $\gamma$-terpinene.

\section{ACKNOWLEDGEMENTS}

Special thanks to staff members of Pharmacology Unit, Cancer Biology Department, National Cancer Institute, Cairo University, Egypt, for assessment of cytotoxic evaluation in this study

\section{CONFLICT OF INTEREST}

The authors report no declarations of interest.

\section{ABBREVIATION USED}

A: The essential oils of the aerial parts, DMSO: Dimethyl sulfoxide, F: The essential oil of the flower, GC/FID: Gas chromatography/Flame ionization detector, GC/MS: Gas chromatography/Mass spectrometry analysis, $\mathbf{I C}_{50} \%$ : The dose of the test solutions which reduces survival to $50 \%, \mathbf{R I}$ : Retention indices, $\mathbf{R}_{\mathrm{t}}$ : Retention times, SD: Standard deviation, SRB: Sulforhodamine B stain assay.

\section{REFERENCES}

1. Batanouny $\mathrm{KH}$, Abou Tabl S, Shabana M and Soliman F. Plants of potential medicinal value, In: Wild medicinal plants in Egypt. Swiss Development Co-operation (SDC), Switzerland. 1999.

2. Mossa JS, Al-Yahya MA and Al-Meshal IA. Medical Plants of Saudi Arabia, Vol.1. King Saud University Libraries, Riyadh. 1987

3. Al-Yahya MA, Al-Rehaily AJ, Mohammed SA, Mansourn S and Farouk S. New alkaloid from Haplophyllum tuberculatum. J. Nat. Prod. 1992; 55(7):899-903.

4. Mohamed AH, Ali MB, Bashir AK and Salih AM. Influence of Haplophyllum tuberculatum on the Cardiovascular System. Pharm. Biol. 1996; 34(3): 213-7.

5. Al-Shamma A, Al-Douri NA and Phillipson JD. Alkaloids of Haplophyllum tuberculatum from Iraq, Phytochemistry. 1979; 18(8):1417-9.

6. Zalzala HA, Al-Shamma A. Medicinal Plants of Iraq I. Phytochemical Investigation of Haplophyllum tuberculatum II. Volatile oil components. Bull. Biol. Res. Cent. 1979; $11(1): 25-31$

7. Ulubelen A and Öztürk M. Alkaloids, coumarins and lignans from Haplophyllum species, Rec. Nat. Prod. 2008; 2(1): 54-69

8. Diar A, Jawad E, Al-Khateeb E, Al-Shamma A. Qualitative and Quantitative investigations of Furocoumarin derivatives (Psoralens) Haplophyllum tuberculatum of (Rutaceae). AJPS. 2005; 2 (2):1-13

9. The Egyptian Pharmacopoeia. Central Administration of Pharmaceutical Affairs (CAPA). $4^{\text {th }}$ ed., Ministry of Health and Population, Cairo, Egypt. 2005.

10. Adams RP. Identification of Essential Oil Components by Gas Chromatography/Mass Spectroscopy. AlluredPublishing Corporation Carol Stream, Illinois, USA. 2004.

11. Woerdenbag H, Bos R, Salomons C, Hendriks H, Pras N, Malingre T. Volatile 
constituents of Artemisia annua L. (Asteraceae).Flavour Fragr. J. 1993; 8(3): 131-7.

12. Palá-Paúl J, Pérez-Alonso M, Velasco-Negueruela A, Ramos- Vázquez P, Gómez Contrera F and Sanz J. Essential oil of Santolina rosmarinifolia L. ssp. rosmarinifolia: first isolation of capillene, a diacetylene derivative. Flavour Fragr. J. 1999; 14(2):131-4.

13. Skehan P, Storeng R, Scudiero D, Monks A, McMahon J, Vistica D, Warren JT, Bokesch H, Kenney S. and Boyd M R. New colorimetric cytotoxicity assay for anticancer-drug screening. J Natl Cancer Inst. 1990; 82(13): 1107-12.

14. Karber G. Pharmacologische Methoden zur Auffindung Von Arzneimittein und Giffter und Analyse Seiner Wirking Sweise,Von Dr. Med. Leopold. Ther. Wissenschoftliche Verlag Gess. Gesellschaft, Gmbh. 1941.

15. Romeilah RM. Anticancer and antioxidant activities of Matricaria chamomilla
L. and Marjorana hortensis essential oils. Research Journal of Medicine and Medical Sciences. 2009; 4(2): 332-9.

16. El-Moataz Bellah El-Naggar, Salama M. El-Darier, Adel Abdalla Sayeda El-Mekanen, Emil Švajdlenka and Milan emlièka. Chemical Composition of Essentia Oil of Haplophyllum tuberculatum. (Rutaceae) Grow Wild in Different Habitats of Egypt, global Journal of Pharmacology. 2014; 8(3): 385-93.

17. Al-Yousuf MH, Bashir A K, Veres K, Dobos A, Nagy N, Mathe I, Blunden G and Vera JR. Haplophyllum tuberculatum Essential oil of (Forssk.) A. Juss. from the United Arab Emirates. J. Essent. Oil Res. 2005; 17(5): 519-21.

18. Javidnia K, Miri R and Banani A. Volatile oil of Haplophyllum tuberculatum (Forssk.) A. Juss. (Rutaceae) from Iran. J. Essent. Oil Res. 2006; 18(4): 355-6.

19. Khalid SA and Waterman PG. Alkaloid, lignan and flavonoid constituents of Haplophyllum tuberculatum from Sudan. Planta Med. 1981; 43(2): 148-52.

\section{PICTORIAL ABSTRACT}

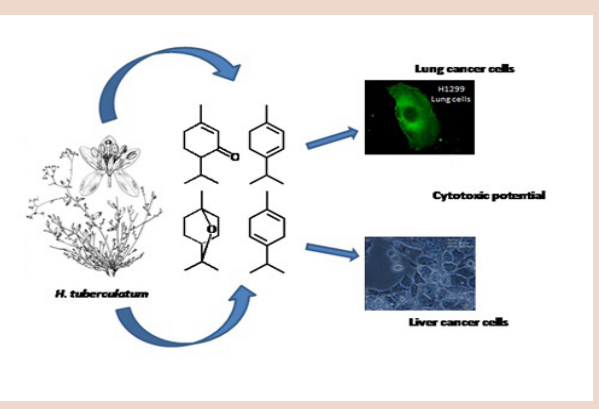

\section{SUMMARY}

- GC/MS analyses of the aerial parts and flowers of $H$. tuberculatum grow ing in Libya were performed.

- Analyses resulted in identification of total 35 compounds. 15 compounds were common to both oils.

- Oils at different concentrations $(0-50 \mu \mathrm{g} / \mathrm{ml})$ in DMSO were tested for cytotoxicity against human tumor cell lines.

- Essential oil of the aerial parts of $H$. tuberculatum is potentially active against lung (H-1299), and liver (HEPG2) carcinoma cell lines.

- The observed cytotoxic activities can be attributed to the dominance of $\mathbb{\Delta}$ and $\gamma$-terpinene in this oil.

\section{ABOUT AUTHORS}

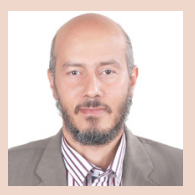

Dr. Omar M. M. Sabry: Received his Ph.D. In medicinal and natural products chemistry from Oregon State University, college of Pharmacy in 2004, having had Professor William H. Gerwick as his major advisor. His major field of specialization is Pharmaceutical sciences. His minor fields of specialization are medicinal and natural products chemistry, botany and medicinal plants, Pharmacognosy, marine natural products chemistry, herbal and alternative medicine. His research interests are quality control of alternative medicine preparations, isolation and structural elucidation of bioactive secondary metabolites from natural sources, detection of herbal medicinal preparations adulteration with synthetic chemical substances.

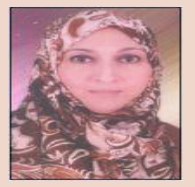

Abeer M. El Sayed: Is a lecturer at the Department of Pharmacognosy, Faculty of Pharmacy, Cairo University, Egypt. Her research interest is in the area of medicinal plants and its biological potentiality. At faculty of pharmacy additionally, she is also a manger assistance for the medicinal, aromatic, poisonous plant experimental station.

Dr. Salmin K. Alshalmani: Got her Ph.D. in Pharmacy, School of Biomedical Sciences, Nottingham University UK in 2011.

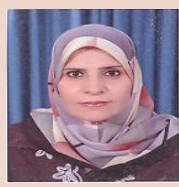

Research Interests of Dr. Salmin are:

1. Isolation and Structure Elucidation of Secondary Metabolites From Natural Sources "Terrestrial Plants And Marine Organisms" With Important BioPharmaceutical Properties Such As Anticancer, Antimicrobial, Anti- inflammatory and Antiviral Activities Using Different Advanced Chromatographic and Spectroscopic Techniques.

2. Running biological and pharmacological screening for chemical, natural and semi-synthetic compounds.

3. Formulation of natural products as complementry and alternative medicine. 